\title{
ХРОНІЧНА ІШЕМІЯ ГОЛОВНОГО МОЗКУ: ДЕЯКІ ОСОБЛИВОСТІ ПРОЦЕСІВ АПОПТОЗУ ЛЕЙКОЦИТІВ КРОВІ, ОКИСНОГО СТРЕСУ ТА МІТОХОНДРІАЛЬНОЇ ДИСФУНКЦІї
}

\author{
๑Р. Б. Насалик, С. І. Шкробот, Н. Р. Сохор, Х. В. Дуве \\ Тернопільський національний медичний університет імені І. Я. Горбачевського МОЗ України
}

РЕзюМЕ. Вивчення показників раннього та пізнього апоптозу, окисного стресу та мітохондріальної дисфункції, з' ясування їх зв' язку з когнітивними розладами сприяють удосконаленню діагностичних підходів та оптимізації прогнозування перебігу захворювання.

Мета - вивчення показників раннього та пізнього апоптозу, окисного стресу та мітохондріальної дисфункції у хворих із хронічною ішемією головного мозку (ХІM) у поєднанні з гідроцефалією (ГЦ).

Матеріал і методи. Проведено комплексне обстеження 140 пацієнтів з XIM та ГЦ. Враховували локалізацію ГЦ, дані Монреальського когнітивного тесту. Дослідження показників апоптозу, мітохондрільної дисфункції, внутрішньоклітинного окисного стресу здійснено цитофлуориметричним методом за допомогою проточного цитофлуориметра EpicsXL (Beckman Coulter, США). Оцінювали дані комп'ютерної томографії головного мозку з подальшим визначенням морфометричних показників та індексів. Для статистичної обробки результатів користувались програмами Microsoft Excel 2011, Statistica.

Результати. Встановлено, що у хворих із ХІМ з ГЦ достовірно $(p<0,05)$ вищий вміст лейкоцитів у стадії апоптозу та некрозу і лейкоцитів із підвищеним вмістом внутрішньоклітинних АФК та зі зниженим мітохондріальним потенціалом, порівняно з пацієнтами без ГЦ. Установлено достовірно вищий відсоток клітин у стадії раннього апоптозу, AФК ${ }^{+}-$та Mito+-клітин при помірному та тяжкому ступенях ГЦ, порівняно з хворими з легкою ГЦ (р<0,001). Установлено достовірно відмінні значення вмісту $\mathrm{ANV}^{+}-$, АФК+-Клітин $(p<0,001)$ у хворих $1 \mathrm{~A}$ та 1 В груп, порівняно $з$ пацієнтами $1 Б$ групи (р<0,001), особливо у 1А групі хворих з переважним розширенням передніх рогів БШ $(20,84 \pm 0,54) \%$.

Вміст клітин у стадії апоптозу у 1 та 2 групах становив, відповідно, $(18,35 \pm 1,12) \%$ та $(14,49 \pm 0,59) \%$, у стадії некрозу - $(1,40 \pm 0,09) \%$ та $(1,14 \pm 0,10) \%$, АФК'-клітин - $(20,50 \pm 1,41) \%$ та $(16,94 \pm 1,29) \%$, Міtо+-клітин - $(8,63 \pm 0,23)$ та $(10,19 \pm 0,20) \%$. Установлено достовірно вищі показники ANV+-, PI+-, AФК+- та Mito+-клітин за наявності ГЦ (р<0,05).

Висновки. Виявлена залежність між морфометричними показниками, які свідчать про підкіркову та кіркову церебральну атрофію, вираженням когнітивного дефіциту, формою ГЦ та маркерами раннього та пізнього апоптозу.

КЛючОВІ СлОВА: хронічна ішемія мозку; гідроцефалія; апоптоз; мітохондріальна дисфункція; окисний стрес.

Вступ. Хронічна ішемія мозку (XIM) та гострі цереброваскулярні захворювання $є$ однією з найважливіших медичних і соціальних проблем в усьому світі з огляду на їх значну поширеність та тяжкі наслідки.

Доволі поширеним явищем $є$ поєднання XIM та гідроцефалії (ГЦ) [1]. 3 однієї сторони, така комбінація можлива, власне, при одночасній наявності XIM та нормотензивної гідроцефалії (НТГ), з іншої - це пояснюється морфологічною стадійністю прогресування XIM (як приклад - замісна гідроцефалія при атрофічних процесах), набряку [2]. У значної частини пацієнтів із гідроцефалією знаходять безліч дрібних ішемічних вогнищ, або лейкоареозу, що не суперечить діагнозу, оскільки можливе поєднання нормотензивної гідроцефалії і цереброваскулярної недостатності [3].

Смерть нейронів гіпокампа $є$ ключовим фактором судинної деменції (СД), спричиненої гіпоперфузією при XIM. Судинна гіпотеза свідчить про те, що помірна та стійка хронічна церебральна гіпоперфузія призводить до васкулотоксичних та нейротоксичних ефектів через зменшення загального об'ємного кровотоку та тривалу гіпоксію, що сприяє нейродегенерації та когнітивним порушен- ням [4]. У нервово-судинних одиницях мозку нейрони $\epsilon$ електрично функціональними клітинами і вимагають постійного надходження глюкози та кисню [5]. Смерть нейронів, яка $є$ основною причиною втрати нейронів, $\epsilon$ ключовою ознакою СД, пов' язаної з XIM [6].

Посилення апоптозу та судинного опору при СД виникає в результаті епендимального просякання, порушення потоку інтерстиціальної рідини, вазогенного набряку та ураження перивенулярної білої речовини. Крім того, спостерігається перерозподіл та накопичення бета-амілоїду по периваскулярних просторах [6]. Окислювальний стрес також відіграє ключову роль у розвитку церебральної ішемії, і взамодія еNOS та активних форм кисню спричиняє аберантний розпад ліпідів. Це призводить до відкладання токсичних продуктів у судинній стінці, пошкодження ДНК та запрограмованої загибелі клітин.

ГЦ сама по собі може викликати зниження загального об' ємного кровотоку та посилення ішемії мозку, а, отже, й процеси загибелі нейронів [7].

Мета - вивчення показників раннього та пізнього апоптозу, окисного стресу та мітохондріальної дисфункції у хворих із XIM у поєднанні з ГЦ. 
Огляди літератури, оригінальні дослідження, погляд на проблему, випадок з практики, короткі повідомлення

Матеріал і методи дослідження. Обстежено 140 хворих (67 (47,86 \%) жінок та 73 (52,14\%) чоловіки) з ХІМ віком від 44 до 82 років (середній вік $((65,78 \pm 9,11)$ роки), які отримували стаціонарне лікування в Тернопільській обласній комунальній клінічній психоневрологічній лікарні. У всіх хворих була діагностована гіпертонічна хвороба, яка поєднувалася з церебральним атеросклерозом у 77 (55,00 \%), з IXC - у 28 (20,00\%), зі стенокардією напруги - у 5 (3,57 \%), із цукровим діабетом - у 10 (7,14\%) осіб. Гостре порушення мозкового кровообігу в анамнезі було у 34 (24,29 \%) хворих. ХІМ I ст. діагностовано у 30 (21,43\%), ХІМ II ст. - у 90 (64,29 \%), XIM III ст. - у 20 (14,29 \%) хворих. Усіх хворих було поділено на дві групи. Першу групу склали 110 (78,57 \%) хворих із XIM, у яких діагностовано ознаки внутрішньої - у 37 (33,64 \%) - 1А група; зовнішньої-у 26 (18,57\%) \%) 1Б група; чи змішаної ГЦ - у 47 (47,73 \%) хворих \%) - 1В група. Легкий ступінь ГЦ було встановлено у 26 (23,64 \%), помірний - у 57 (51,82 \%), тяжкий - у 27 (24,55 \%) пацієнтів. До 2 групи (групи порівняння) увійшли 30 (21,43 \%) пацієнтів з ХІМ без проявів ГЦ. Контрольну групу (КГ) склали 20 практично здорових осіб, репрезентативних за віком та статтю. Стан когнітивних функцій оцінювали за Монреальською шкалою когнітивних функцій (МоСА-тест). Нейровізуалізацію прово- дили за допомогою спіральної комп' ютерної томографії (KT) на апараті фірми Asteion 4 (Toshiba). Дослідження показників апоптозу, мітохондріальної дисфункції, внутрішньоклітинного окисного стресу здійснювали цитофлуориметричним методом за допомогою проточного цитофлуориметpa EpicsXL (Beckman Coulter, США). Кількість лейкоцитів периферійної крові в стадії апоптозу ( $\mathrm{ANV}^{+}-$-клітини) і некрозу ( $\mathrm{Pl}^{+}-$-клітини) визначали за допомогою набору реагентів ANNEXIN V-FITC-kit (Bender Medsystems, Австрія), кількість лейкоцитів периферійної крові з підвищеним рівнем внутрішньоклітинних АФК (АФК могою дихлорфлуоресцеїну діацетату («SigmaAldrich", USA), кількість лейкоцитів зі зниженим рівнем потенціалу мітохондріальних мембран (Mito+-клітини) - за допомогою набору реагентів Mito Capture TM Mitochondrial Apoptosis Detection Fluorometric Kit («Biovision», США).

Статистичний аналіз проводили на персональному комп' ютері з використанням програми Statistica v. 6.1.

Результати й обговорення. Встановлено, що у хворих з ХІМ спостерігався достовірно $(p<0,05)$ вищий вміст лейкоцитів у стадії апоптозу та некрозу і лейкоцитів з підвищеним вмістом внутрішньоклітинних АФК та Mito--клітин по відношенню до КГ (табл. 1).

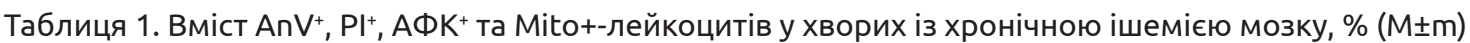

\begin{tabular}{|l|c|c|}
\hline \multicolumn{1}{|c|}{ Показник } & $\mathrm{KГ}(\mathrm{n}=20)$ & Хворі з XIM (n=140) \\
\hline ANV $^{+}$-клітини & $3,05 \pm 0,52$ & $17,89 \pm 0,64^{*}$ \\
\hline $\mathrm{PI}^{+}-$клітини & $0,29 \pm 0,04$ & $1,34 \pm 0,05^{*}$ \\
\hline АФК+-клітини & $10,06 \pm 0,35$ & $19,08 \pm 0,72^{*}$ \\
\hline Mito+-клітини & $4,08 \pm 0,16$ & $9,16 \pm 0,21^{*}$ \\
\hline
\end{tabular}

Примітка. * показники достовірні по відношенню до значень КГ $(p<0,001)$.

Проведено оцінку процесів раннього та пізнього апоптозу, окисного стресу та мітохондріальної дисфункції у хворих 1 (з ГЦ) та 2 груп (без ГЦ). У хворих обох груп відмічалися достовірно відмінні значення усіх визначуваних параметрів. Проте, встановлено достовірно вищі показники $\mathrm{ANV}^{+}-, \mathrm{Pl}^{+}-, \mathrm{AФK}^{+}-$та Mito+-клітин за наявності ГЦ $(p<0,05)$. Так, вміст клітин у стадії апоптозу у 1 та 2 групах становив відповідно $(18,35 \pm 1,12) \%$ та
$(14,49 \pm 0,59) \%$, у стадії некрозу $(1,40 \pm 0,09) \%$ та $(1,14 \pm 0,10) \%$, АФК'-клітин $(20,50 \pm 1,41) \%$ та $(16,94 \pm 1,29) \%$, Mito+-клітин $(8,63 \pm 0,23)$ та $(10,19 \pm 0,20) \%$. Тобто, наявність ГЦ при ХІМ поєднувалася з достовірно вищим зростанням активності апоптичних процесів.

Досліджено вміст вміст $\mathrm{AN}^{+}, \mathrm{Pl}^{+}-, \mathrm{AФK}^{+}-$та Mito+-клітин у хворих з XIM в залежності від форми ГЦ (табл. 2).

Таблиця 2. Вміст $\mathrm{ANV}^{+}, \mathrm{PI}^{+}, \mathrm{AФK}^{+}$та Mito+-клітин у хворих з хронічною ішемією мозку залежно від ступеня

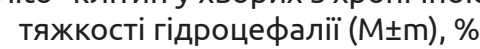

\begin{tabular}{|l|c|c|c|}
\hline \multirow{2}{*}{\multicolumn{1}{|c|}{ Показник }} & \multicolumn{3}{|c|}{ Групи хворих } \\
\cline { 2 - 4 } & $1 \mathrm{~A}, \mathrm{n}=37$ & $1 \mathrm{~b}, \mathrm{n}=26$ & $1 \mathrm{~B}, \mathrm{n}=47$ \\
\hline $\mathrm{ANV}^{+}-$-клітини & $19,69 \pm 0,70^{*}$ & $14,54 \pm 0,64$ & $1,31 \pm 0,08^{*}$ \\
\hline $\mathrm{PI}^{+}-$-клітини & $1,28 \pm 0,06^{*}$ & $1,49 \pm 0,06$ & $22,21 \pm 0,47^{*}$ \\
\hline АФК+-клітини & $23,12 \pm 0,52^{*}$ & $17,30 \pm 0,34$ & $9,03 \pm 0,24$ \\
\hline Міто -клітини & $8,81 \pm 0,51^{*}$ & $10,69 \pm 0,50$ & \\
\hline
\end{tabular}

Примітка. * показники достовірні по відношенню до значень хворих 15 групи $(p<0,001)$. 
Огляди літератури, оригінальні дослідження, погляд на проблему, випадок з практики, короткі повідомлення

При всіх формах ГЦ спостерігалися достовірно вищі показники $\mathrm{ANV}^{+}$-клітин, порівняно з КГ $(p<0,001)$. Установлені достовірні відмінності значення вмісту $\mathrm{ANV}^{+}-$-клітин у хворих $1 \mathrm{~A}$ та $1 \mathrm{~B}$ груп по відношенню до пацієнтів 1Б групи ( $<<0,001)$. Найвищий рівень лейкоцитів у стадії апоптозу зафіксовано у 1 А групі хворих із переважним розширенням передніх рогів бокових шлуночків (БШ) $(20,84 \pm 0,54) \%$. Не діагностовано достовірної різниці у кількості клітин у стадії некрозу в хворих із різними формами ГЦ $(p>0,05)$, хоча найвищий рівень $\mathrm{Pl}^{+}-$-клітин спостерігався у хворих 1 Б групи. Співвідношення між кількістю лейкоцитів у стадії апоптозу та некрозу в 1 А групі склало $1: 15,38$, у $1 Б$ - 1:9,75, у 1В - 1:13,96. Отримані дані свідчать про те, що у клітинній загибелі при внутрішній та змішаній формах ГЦ при XIM переважають апоптичні процеси і менш активуються процеси некрозу, що було найбільше виражено у пацієнтів $1 \mathrm{~A}$ групи. При зовнішній ГЦ при XIM найбільшою мірою, порівняно з іншими хворими 1 групи, активувалися процеси некрозу.

Bміст Mito+-клітин був достовірно вищим при різних формах ГЦ, порівняно з КГ $((p<0,001)$. Порівняно з показниками хворих 1А та 1В груп, кількість клітин зі зниженим мітохондріальним потенціалом у 1Б групі була дещо вищою, проте достовірної відмінності виявлено не було. Спостерігалася залежність між кількістю $\mathrm{ANV}^{+}$- та Mito+-клітин при всіх формах ГЦ: 1 А $-(r=0,31$, $p=0,040), 15-(r=0,29, p=0,036), 1 B-(r=0,27$, $\mathrm{p}=0,043)$. Також встановлено кореляцію між вмістом $\mathrm{Pl}^{+}-$та Mito'-клітин у хворих 15 групи ( $r=0,45$, $\mathrm{p}=0,021$ ). Отримані дані, ймовірно, свідчать про те, що в процесах апоптозу, які в більшій мірі виражені при внутрішній та змішаній ГЦ, домінуючу роль відігравали активні форми кисню, і в меншій мірі - мітохондріальна дисфункція. У хворих із ознаками зовнішньої ГЦ у процесах некрозу лейкоцитів крові відмічена переважна роль порушення трансмембранного мітохондріального потенціалу і меншою мірою - окисного стресу.

Для визначення значення процесів апоптозу та некрозу в розвитку атрофічного процесу в хворих із XIM з гідроцефалією ми провели кореляційний аналіз морфометричних показників із вмістом $\mathrm{ANV}^{+}$, $\mathrm{Pl}^{+}-$, $\mathrm{AФ \textrm {K } ^ { + } - т а}$ Mito+-клітин. Установлені такі кореляції. У хворих $1 \mathrm{~A}$ та 1В груп: $\mathrm{ANV}^{+}-$-клітини / бікаудатний індекс (БKI) - $(r=0,42 ; p=0,020), \mathrm{ANV}^{+}-$ клітини / біфронтальний індекс (БФІ) - $(r=0,48$; $p=0,017)$. У хворих із морфометричними ознаками внутрішньої ГЦ (1А група) встановлено помірний зв' язок між кількістю АФК'-клітин та числом Еванса $(r=0,41 ; p=0,033)$ та $\mathrm{ANV}^{+}$-клітин із показниками, які характеризують ширину бічних шлуночків: БКІ $(r=0,50 ; p=0,008)$ та БФІ $(r=0,53 ; p=0,005)$.
У хворих із зовнішньою ГЦ установлено кореляційну залежність між концентрацією $\mathrm{PI}^{+}-$-клітин із шириною субарахноїдальних просторів (САП) на рівні полюсів лобних і потиличних часток ( $r=-$ 0,$42 ; p=0,020$ й г=0,37; $p=0,006$ відповідно). Також виявлена залежність між вмістом лейкоцитів у стадії некрозу з наступними морфометричними індексами: БФІ ( $r=-0,32 ; p=0,012) ;$ БKI $(r=-0,30$; $\mathrm{p}=0,020)$. Відсоток $\mathrm{AnV}^{+}-$клітин слабо корелював із бітемпоральним індексом $(r=-0,25 ; p=0,040)$ та БKI $(r=-0,29 ; p=0,035)$.

Отже, отримані результати дозволяють констатувати наявність у хворих 1A та 1В груп помірної залежності між морфометричними маркерами внутрішньої ГЦ та показниками, які характеризують стан процесів апоптозу та генерації АФК у периферичній крові. У хворих із зовнішньою ГЦ установлено помірну кореляційну залежність між концентрацією $\mathrm{PI}^{+}-$-клітин та шириною САП та слабку - між кількістю клітин у стадії апоптозу і некрозу із значеннями БКІ та БФІ.

Встановлена залежність між деякими показниками когнітивної і психоемоційної сфер із показниками апоптозу та окисного стресу. Так, у хворих 1А та 1В груп виявлені такі кореляції: $\mathrm{AnV}^{+}-$клітини / МоСА-тест - $г=-0,58 ; \mathrm{p}=0,005, \mathrm{AnV}^{+}$-клітин та «зорово-конструктивні навички» $(r=-0,61 ; p=0,005), \mathrm{AnV}^{+}$ клітини / HADS депресія - $r=0,39, p=0,005, A Ф K^{+}$ клітини / депресія $(r=0,49 ; p=0,010), А Ф K^{+}-$клітини / MoCA $(r=0,52 ; p=0,008)$. За іншими показниками фіксувалися слабкі кореляційні зв'язки. Одночасно діагностовані кореляції між морфометричними показниками (БКІ, БФІ, числом Еванса) та вмістом

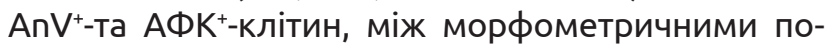
казниками (БКІ, шириною лівого шлуночка) зі значенням шкали МоСА, підшкалами «мовлення», «зорово-конструктивні навички», «орієнтація», тривогою та депресією можуть свідчити про наростання когнітивних та психоемоційних змін у зв' язку з посиленням окисного стресу, апоптозом клітин, що призводять до атрофічних змін речовини мозку і, як наслідок, до розвитку порушень пам'яті та емоційно-вольових розладів.

У $1 Б$ групі спостерігалася наступна залежність: $\mathrm{Pl}^{+}$-клітини / MoCA ( $\left.r=0,48 ; \mathrm{p}=0,012\right), \mathrm{Pl}^{+-}$клітини / «тривожність» $(r=0,53 ; p=0,008), \mathrm{Pl}^{+}$-клітини / депресія $(r=0,60 ; p=0,008)$. Виявлені кореляційні зв'язки між показником мітохондріальної дисфункції (Mito+-клітини) та такими параметрами: МoCA $(r=0,55 ; p=0,006)$, «тривожність» $(r=0,45 ; p=0,010)$.

Дослідження кореляційних зв' язків між окремими морфометричними індексами та даними лабораторного дослідження підтвердило наявність статистично значущої залежності між часткою $\mathrm{Pl}^{+}-$ клітин й шириною САП на рівні лобних і потиличних часток та результатом МоСа-тесту. 
Огляди літератури, оригінальні дослідження, погляд на проблему, випадок з практики, короткі повідомлення

Проведений аналіз процесів раннього та пізнього апоптозу у хворих із XIM 1 групи в залежності від ступеня тяжкості гідроцефалії (табл. 3).

Результати, отримані у хворих з ХІМ, достовірно ( $p=0,001)$ відрізнялися від значень контролю, що свідчить про активацію процесів апоптозу лейкоцитів периферійної крові в усіх групах. Установлено достовірно вищий відсоток клітин у стадії раннього апоптозу при помірному та тяжкому ступенях ГЦ, порівняно з хворими з легкою ГЦ

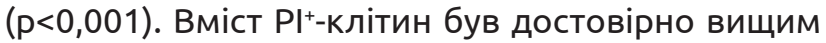
лише при тяжкій ГЦ, порівняно з хворими із легкою ГЦ. Співвідношення $\mathrm{Pl}^{+}-/ \mathrm{AnV}^{+}-$клітин у даних групах коливалося в межах від 1:12,87 (легка ГЦ) до 1:14,95 (тяжка ГЦ), при значенні контрольної групи 1:10,51. Цей факт вказує на дисбаланс процесів раннього та пізнього апоптозу при різних ступенях тяжкості ГЦ.

Таблиця 3. Вміст $\mathrm{AN}^{+}-$, $\mathrm{PI}^{+-}$, АФК+- та Мito+-клітин у хворих з хронічною ішемією мозку залежно від ступеня

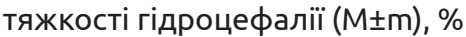

\begin{tabular}{|l|c|c|c|}
\hline \multirow{2}{*}{\multicolumn{1}{|c|}{ Показник }} & \multicolumn{3}{|c|}{ Ступінь тяжкості ГЦ } \\
\cline { 2 - 4 } & легкий, $\mathrm{n}=26$ & помірний, $\mathrm{n}=57$ & тяжкий, $\mathrm{n}=27$ \\
\hline $\mathrm{ANV}^{+}$-клітини & $16,22 \pm 0,74$ & $18,95 \pm 0,89^{*}$ & $1,38 \pm 0,53^{*}$ \\
\hline $\mathrm{PI}^{+}-$-клітини & $1,26 \pm 0,09$ & $1,35 \pm 0,06$ & $22,91 \pm 0,63^{*}$ \\
\hline АФК+-клітини & $16,85 \pm 0,60$ & $19,73 \pm 0,80^{*}$ & $10,75 \pm 0,20^{*}$ \\
\hline Міто+-клітини & $8,31 \pm 0,27$ & $9,23 \pm 0,28^{*}$ & \\
\hline
\end{tabular}

Примітка. * - показники достовірні по відношенню до значень хворих із легкою ГЦ ( $p<0,001)$.

Свідченням активації окисного стресу при різних ступенях тяжкості ГЦ $є$ достовірно $(p<0,01)$ вища за контрольні значення частка АФК+-клітин: $(16,85 \pm 0,60) \%$ - легка ГЦ, $(19,73 \pm 0,80) \%$ - помірна ГЦ та $(22,91 \pm 0,63) \%$ - тяжка ГЦ. Між значеннями у групах показники АФК ${ }^{+-к л і т и н ~ п р и ~ т я ж к і и ̆ ~ Г Ц ~ с т а-~}$ тистично достовірно відрізнялися від значень хворих із легкою та помірною ГЦ $(p<0,05)$.

При легкій ГЦ не зафіксовано достовірних ко-

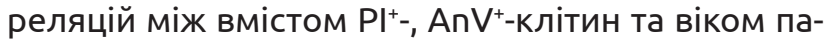
цієнтів. У групі хворих із помірною ГЦ виявлено слабку ( $r=0,28 ; p=0,036)$, а при тяжкій ГЦ- помірну $(r=0,37 ; p=0,020)$ залежність між віком хворих i часткою $\mathrm{AnV}^{+}-$-клітин. Найвищий рівень усіх досліджуваних показників був у хворих старше 74 років при тяжкому ступені ГЦ.

Висновки. 1. У хворих із XIM з ГЦ виявлено достовірно $(p<0,05)$ вищий вміст лейкоцитів у стадії апоптозу та некрозу і лейкоцитів з підвищеним вмістом внутрішньоклітинних АФК та зі зниженим мітохондріальним потенціалом, порівняно 3 пацієнтами без ГЦ.

2. Встановлено достовірно вищий відсоток клітин у стадії раннього апоптозу, АФК- та Mito+клітин при помірному та тяжкому ступенях ГЦ, порівняно з хворими з легкою ГЦ (p<0,001). Вміст $\mathrm{Pl}^{+}-$-клітин був достовірно вищим лише при тяжкій ГЦ, порвняно з хворими із легкою ГЦ.

3. При всіх формах ГЦ спостерігалися достовірно вищі показники $\mathrm{ANV}^{+}-$клітин, порівняно з КГ. Установлено достовірно відмінні значення вмісту $\mathrm{ANV}^{+}$, АФК ${ }^{+}-$клітин ( $\left.\mathrm{p}<0,001\right)$ у хворих 1A та 1В груп, по відношенню до пацієнтів 1Б групи ( $p<0,001)$, особливо у 1А групі хворих із переважним розширенням передніх рогів БШ $(20,84 \pm 0,54) \%$. Не виявлено достовірної різниці у кількості $\mathrm{Pl}^{+}-$та Mito+клітин у хворих з різними формами ГЦ.

4. При внутрішній та змішаній формах ГЦ при XIM встановлено переважаючу роль у клітинній загибелі апоптичних процесів і меншу активацію процесів некрозу. У процесах апоптозу домінуючу роль відігравали АФК, і в меншій мірі - мітохондріальна дисфункція. При зовнішній ГЦ найбільше, порівняно з іншими хворими 1 групи, активувалися процеси некрозу і порушення трансмембранного мітохондріального потенціалу.

\section{ЛІТЕРАТУРА}

1. Дамулин И. В. Падения у пожилых / И. В. Дамулин. - М., 2005. -152 с.

2. Williams M. A. Diagnosis and management of idiopathic normal pressure hydrocephalus / M. A. Williams, N. R. Relkin // Neurol. Clin. Pract. - 2013. - Vol. 3 (5). P. 375-385.

3. A review of cognitive impairment and differential diagnosis in idiopathic normal pressure hydrocephalus /
M. Picascia, R. Zangaglia, S. Bernini [et al.] // Funct. Neurol. - 2015. - Vol. 30 (4). - P. 217-229.

4. Raz L. The neuropathology and cerebrovascular mechanisms of dementia / L. Raz, J. Knoefel, K. Bhaskar // J. Cereb. Blood Flow Metab. - 2016. - Vol. 36 (1). P. 172-186.

5. Protective effects of sulforaphane in experimental vascular cognitive impairment: contribution of the Nrf2 
Огляди літератури, оригінальні дослідження, погляд на проблему, випадок з практики, короткі повідомлення pathway / L. Mao, T. Yang, X. Li [et al.] // J. Cereb. Blood Flow Metab. - 2019. - Vol. 39 (2). - P. 352-366.

7. Current concepts on the pathophysiology of idio-

6. MicroRNA-195 prevents dendritic degeneration and neuron death in rats following chronic brain hypoperfusion / X. Chen, X. M. Jiang, L. J. Zhao [et al.] // Cell Death Dis. 2017. - Vol. 8 (6). - e2850. DOI: 10.1038/cddis.2017.243. pathic chronic adult hydrocephalus: Are we facing another neurodegenerative disease? / R. Martín-Láez, N. Valle-San Román, E. M. Rodríguez-Rodríguez [et al.] // Neurologia (Engl. Edn.). - 2018. - Vol. 33 (7). - P. 449-458.

\section{REFERENCES}

1. Damulin, I.V. (2005). Padeniya u pozhilykh [Falls in the elderly]. Moscow [in Russian].

2. Williams, M.A., \& Relkin, N.R. (2013). Diagnosis and management of idiopathic normal pressure hydrocephalus. Neurol. Clin. Pract., 3 (5), 375-385. DOI: 10.1212/ CPJ.0B013E3182A78F6B

3. Picascia, M., Zangaglia, R., Bernini, S., Minafra, B., Sinforiani, E., \& Pacchetti, C. (2015). A review of cognitive impairment and differential diagnosis in idiopathic normal pressure hydrocephalus. Funct. Neurol., 30 (4), 217-229. DOI: 10.11138/fneur/2015.30.4.217

4. Raz, L., Knoefel, J., \& Bhaskar, K. (2016). The neuropathology and cerebrovascular mechanisms of dementia. J. Cereb. Blood Flow Metab., 36 (1), 172-186. DOI: 10.1038/ jcbfm.2015.164

5. Mao, L., Yang, T., Li, X., Lei, X., Sun, Y., Zhao, Y., \& Zhang, F. (2019). Protective effects of sulforaphane in experimental vascular cognitive impairment: contribution of the Nrf2 pathway. J. Cereb. Blood Flow Metab., 39 (2), 352366. DOI: $10.1177 / 0271678 \times 18764083$

6. Chen, X., Jiang, X.M., Zhao, L.J., Sun, L.L., Yan, M.L., Tian, Y., \& Ai, J. (2017). MicroRNA-195 prevents dendritic degeneration and neuron death in rats following chronic brain hypoperfusion. Cell Death Dis., 8 (6), e2850. DOI: $10.1038 /$ cddis.2017.243

7. Martín-Láez, R., Valle-San Román, N., Rodríguez-Rodríguez, E.M., Marco-de Lucas, E., Berciano Blanco, J.A., \& Vázquez-Barquero, A. (2018). Current concepts on the pathophysiology of idiopathic chronic adult hydrocephalus: Are we facing another neurodegenerative disease? Neurologia (Eng. Edn.), 33 (7), 449-458.

\section{ХРОНИЧЕСКАЯ ИШЕМИЯ МОЗГА: НЕКОТОРЫЕ ОСОБЕННОСТИ ПРОЦЕССОВ АПОПТОЗА ЛЕЙКОЦИТОВ КРОВИ, ОКИСЛИТЕЛЬНОГО СТРЕССА И МИТОХОНДРИАЛЬНОЙ ДИСФУНКЦИИ \\ ๑Р. Б. Насалык, С. И. Шкробот, Н. Р. Сохор, К. В. Дуве}

Тернопольский национальный медицинский университет имени И. Я. Горбачевского МОз Украины

РЕзЮМЕ. Изучение показателей раннего и позднего апоптоза, окислительного стресса и митохондриальной дисфункции, выяснения их связи с когнитивными расстройствами способствует усовершенствованию диагностических подходов и оптимизации прогнозирования течения заболевания.

Цель - изучение показателей раннего и позднего апоптоза, окислительного стресса и митохондриальной дисфункции у больных хронической ишемией мозга (ХИМ) в сочетании с гидроцефалией (ГЦ).

Материал и методы. Проведено комплексное обследование 140 пациентов с ХИМ и ГЦ. Учитывали локализацию ГЦ, данные Монреальского когнитивного теста. Оценивали данные компьютерной томографии головного мозга с последующим определением морфометрических показателей и индексов. Для статистической обработки результатов пользовались программами Microsoft Excel 2011, Statistica.

Результаты. Установлено, что у больных ХИМ и ГЦ достоверно $(p<0,05)$ выше содержание лейкоцитов в стадии апоптоза и некроза и лейкоцитов с повышенным содержанием внутриклеточных АФК и со сниженным митохондриальным потенциалом по отношению к пациентам без ГЦ. Установлен достоверно более высокий процент клеток в стадии раннего апоптоза, АФК+ - и Mito+ клеток при умеренном и тяжелом степенях ГЦ, по сравнению с больными с легкой ГЦ (р<0,001). Установлены достоверно различающиеся значения содержания ANV+ -, AФK+ клеток $(p<0,001)$ у больных 1A и 1B групп по отношению к пациентам 1Б группы $(p<0,001)$, особенно в 1 А группе больных с преимущественным расширением передних рогов БШ $(20,84 \pm 0,54) \%$.

Содержание клеток в стадии апоптоза в 1 и 2 группах составило, соответственно, $(18,35 \pm 1,12) \%$ и $(14,49 \pm 0,59) \%$, в стадии некроза - $(1,40 \pm 0,09) \%$ и $(1,14 \pm 0,10) \%$, АФК+ клеток - $(20,50 \pm 1,41) \%$ и $(16,94 \pm 1,29) \%$, Mito+ клеток - $(8,63 \pm 0,23)$ и $(10,19 \pm 0,20) \%$. Установлены достоверно более высокие показатели $\mathrm{ANV}^{+-}, \mathrm{PИ}^{+-}, \mathrm{AФK}^{+-}$ и Mito+ клеток при наличии ГЦ (р<0,05).

Выводы. Установлена зависимость между морфометрическими показателями, которые свидетельствуют о подкорковой и корковой церебральной атрофии, выраженностью когнитивного дефицита, формой ГЦ и маркерами раннего и позднего апоптоза.

КЛЮЧЕВЫЕ СЛОВА: хроническая ишемия мозга; гидроцефалия; апоптоз; митохондриальная дисфункция; окислительный стресс. 
Огляди літератури, оригінальні дослідження, погляд на проблему, випадок з практики, короткі повідомлення

\title{
CHRONIC BRAIN ISCHEMIA: SOME FEATURES OF BLOOD LEUCOCYTIC APOPTOSIS PROCESSES, OXIDATIVE STRESS AND MITOCHONDRIAL DIFFUSION
}

\author{
@R. B. Nasalyk, S. I. Shkrobot, N. R. Sokhor, Khr. V. Duve
}

\section{Horbachevsky Ternopil National Medical University}

SUMMARY. The study of indicators of early and late apoptosis, oxidative stress and mitochondrial dysfunction, elucidation of their connection with cognitive disorders contributes to the improvement of diagnostic approaches and optimization of disease prognosis.

The aim - to research the indicators of early and late apoptosis, oxidative stress and mitochondrial dysfunction in patients with $\mathrm{CBI}$ in combination with $\mathrm{HC}$.

Material and Methods. A comprehensive examination of 140 patients with CBI and HC was carried out. We took into account the localization of HC, the data of the Montreal cognitive test. Studies of apoptosis, mitochondrial dysfunction, intracellular oxidative stress were performed by cytofluorimetric method using a flow cytofluorimeter EpicsXL (Beckman Coulter, USA). The data of computed tomography of the brain were evaluated, followed by the determination of morphometric parameters and indices. For statistical processing of the results, we used Microsoft Excel 2011 and Statistica programs.

Results. It was found that in patients with $\mathrm{CBI}$ and $\mathrm{HC}$ significantly $(\mathrm{p}<0.05)$ higher content of leukocytes in the stage of apoptosis and necrosis and leukocytes with high content of intracellular AFO and with reduced mitochondrial potential compared to patients without HC. There was a significantly higher percentage of cells in the stage of early apoptosis, $\mathrm{AFO}^{+}$- and Mito+cells in moderate and severe $\mathrm{HC}$ in comparison with patients with mild $\mathrm{HC}(\mathrm{p}<0.001)$. Significantly different values of the content of $\mathrm{ANV}^{+}$, AFO+cells $(p<0.001)$ in patients of groups $1 \mathrm{~A}$ and $1 \mathrm{~B}$ in relation to patients of group 1B $(p<0.001)$, especially in group $1 \mathrm{~A}$ of patients with predominant enlargement of the anterior horns of the BV $(20.84 \pm 0.54) \%$.

The content of cells in the stage of apoptosis in groups 1 and 2 was $(18.35 \pm 1.12) \%$ and $(14.49 \pm 0.59) \%$, respectively, in the stage of necrosis $(1.40 \pm 0.09) \%$ and $(1.14 \pm 0.10) \%$, AFO cells $(20.50 \pm 1.41) \%$ and $(16.94 \pm 1.29) \%$, Mito cells $(8.63 \pm 0.23)$ and $(10.19 \pm 0.20) \%$. Significantly higher indicators of $\mathrm{ANV}^{+}-, \mathrm{Pl}^{+}-, \mathrm{AFO}^{+}$- and $\mathrm{Mito}^{+}$-cells in case of the presence of HC $(p<0.05)$.

Conclusions. The relationship between morphometric parameters, which indicate subcortical and cortical cerebral atrophy, the severity of cognitive deficits, the form of HC depending on the markers of early and late apoptosis.

KEY WORDS: chronic brain ischemia; hydrocephalusapoptosis; mitochondrial dysfunction; oxidative stress.

Отримано 03.02.2021 